The Archaeology of La Calsada 
Texas Archaeology and Ethnohistory Series Thomas R. Hester, Editor 


\title{
The Archaeology of La Calsada
}

\author{
A Rockshelter in the \\ Sierra Madre Oriental, \\ Mexico
}

\section{BY C. ROGER NANCE}

Foreword by Jeremiah F. Epstein

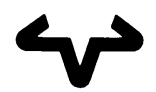

UNIVERSITY OF TEXAS PRESS AUSTIN 
Copyright (C) 1992 by the University of Texas Press

All rights reserved

Printed in the United States of America

First edition, 1992

Requests for permission to reproduce material from this work should be sent to Permissions, University of Texas Press, Box 7819, Austin, TX 78713-7819.

(2) The paper used in this publication meets the minimum requirements of American National Standard for Information Sciences-Permanence of Paper for Printed Library Materials, ANSI Z39.48-1984.

Library of Congress Cataloging-in-Publication Data

Nance, Charles Roger, [date]

The archaeology of La Calsada : a rockshelter in the Sierra Madre

Oriental, Mexico / by C. Roger Nance ; foreword by Jeremiah F.

Epstein. - 1st ed.

p. cm. - (Texas archaeology and ethnohistory series) Includes bibliographical references and index.

ISBN 0-292-70427-5 (cloth)

1. Calsada Rockshelter (Mexico) 2. Indians of Mexico-MexicoNuevo León (State)_Antiquities. 3. Nuevo León (Mexico : State)Antiquities. I. Title. II. Series.

F1219.1.N83N36 1992

972'.13-de20 91-41040

CIP 
To Vally 
THIS PAGE INTENTIONALLY LEFT BLANK 